\title{
EFEKTIVITAS MODEL PEMBELAJARAN INQUIRY TERHADAP HASIL PEMBELAJARAN BIOLOGI SISWAKELAS X SMA NEGERI 6 LUBUKLINGGAU
}

\author{
Destien Atmi Arisandy ${ }^{1}$, Linna Fitriani ${ }^{2}$, Flora Ghassani ${ }^{3}$ \\ STKIP PGRI Lubuklinggau ${ }^{1,2,3}$ \\ destien13destien@gmail.com ${ }^{1}$
}

\begin{abstract}
ABSTRAK
Tujuan penelitian ini untuk mengetahui efektivitas model pembelajaran inquiry terhadap hasil pembelajaran biologi siswa kelas X SMA Negeri 6 Lubuklinggau. Jenis penelitian ini adalah penelitian kuantitatif dengan metode penelitian eksperimen. Populasi yang dipakai adalah seluruh siswa kelas X SMA Negeri 6 Lubuklinggau, yang terdiri dari 213 siswa dan sampel peneliti yaitu kelas X.1 untuk kelas eksperimen dan kelas X.2 untuk kelas kontrol. Pengumpulan data dengan menggunakan tes. Data yang didapatkan dianalisis dengan menggunakan uji-t. Dari penelitian yang sudah dilakukan diperoleh data post-test kelas eksperimen dan kelas kontrol dengan $\alpha=0,05$ didapatkan t-hitung $=4,06$ dan $\mathrm{t}$ tabel $=1,67$, karena t-hitung $>$ t-tabel, berarti rata-rata skor untuk kelas eksperimen lebih tinggi dari pada kelas kontrol, sehingga dapat ditarik kesimpulan bahwa model pembelajaran inquiry efektiv untuk pembelajaran biologi pada siswa kelas X SMA Negeri 6 Lubuklinggau.
\end{abstract}

Kata Kunci: efektivitas, hasil belajar biologi, model pembelajaran inquiry

\begin{abstract}
The purpose of this study was to determine the effectiveness of inquiry learning models on the learning outcomes of biology students in class X SMA Negeri 6 Lubuklinggau. This type of research is quantitative research with experimental research methods. The population used was all students of class X SMA Negeri 6 Lubuklinggau, which consisted of 213 students and a sample of researchers, namely class X.1 for the experimental class and class X.2 for the control class. Data collection using tests. The data obtained were analyzed using t-test. From the research that has been done, it is obtained the post-test data of the experimental class and the control class with $\alpha=0.05$ obtained $t$-count $=4.06$ and $t$-table $=1.67$, because t-count $>t$-table, means the average score for the experimental class is higher than the control class, so it can be concluded that the inquiry learning model is effective for learning biology in class X students of SMA Negeri 6 Lubuklinggau.
\end{abstract}

Keywords: efektivitas, inquiry learning model, results of studying biology. 


\section{PENDAHULUAN}

Pendidikan ataupun pengetahuan adalah suatu kebutuhan manusia, karena pendidikan adalah suatu upaya untuk mendapatkan pengetahuan guna memperoleh perubahan dalam hidup seseorang. Hal ini selaras dengan pendapat Ahmadi \& Uhbiyati (2013) yang mengemukakan bahwa sistem pendidikan yang ada saat ini, dan selama ini diibaratkan sebuah bank. Peserta didik diberikan pengetahuan sehingga nantinya bisa mendatangkan hasil yang berlipatlipat.Peserta didik diibaratkan sebagai wadah kosong dimana akan diisi, sebagai sarana tabungan. Jadi, pendidikan menjadi salah satu bagian penting dalam membangun suatu negara.

Dalam menerapkan pendidikan di sekolah, pastinya melibatkan tenaga pengajar yang biasa disebut guru dan peserta didik (siswa), diwujudkan dengan adanya interaksi proses pembelajaran agar memperoleh sesuatu profesi serta menyelesaikan masalah yang akan dihadapi. Hal ini sesuai dengan pernyataan yang dikemukakan oleh Supriyadi (2014) bahwa pendidikan yang baik adalah pendidikan yang tidak hanya mempersiapkan para siswanya untuk sesuatu profesi atau jabatan ataupun pekerjaan lainnya, tetapi diharapkan bisa menyelesaikan masalah- masalah yang dihadapinya dalam kehidupan sehari-hari.

Belajar bagi siswa pada hakekatnya bukan saja sekedar untuk mengingat dan memahami temuan saintis, tetapi juga diharapkan untuk memperoleh konsepkonsep biologi dan untuk menumbuhkan sikap ilmiah.Proses belajar mengajar biologi di sekolah secara umum terjadi hanya sebagai transfer pengetahuan, sehingga tujuan utama pendidikan seperti penguasaan konsep dan pembentukan sikap ilmiah kurang dapat terbentuk dalam diri anak didik. Untuk mencapai tujuan tersebut, seorang guru biologi dalam menyajikan pelajaran seharusnya menggunakan metode pengajaran yang relevan dengan kebutuhan pembelajaran (siswa dan materi pelajaran), karena metode mengajar akan menentukan tercapai atau tidaknya tujuan pembelajaran.Oleh sebab itu, guru seharusnya memilih dan melaksanakan teknik-teknik mengajar yang tepat sehingga hasil pengajaran dapat dicapai seoptimal mungkin.

Berdasarkan wawancara dari guru biologi di SMA Negeri 6 Lubuklinggau, pada tanggal 21 Maret 2016 mengatakan bahwa hasil belajar siswa kelas X pada mata pelajaran biologi masih rendah.Jumlah total kelas X yaitu 213 orang, hanya 85 orang tuntas dengan persentase ketuntasan $42,76 \%$ dan 116 orang dengan persentase $57,24 \%$ tidak tuntas atau yang belum mencapai batas KKM yang telah ditetapkan sekolah untuk mata pembelajaran biologi kelas X adalah 70 .

Menurut guru biologi di SMA Negeri 6 lubuklinggau, faktor rendahnya hasil belajar dikarenakan siswa kurang aktif dalam belajar dan hanya menerima materi yang bersumber dari guru saja sehingga siswa menjadi pasif.Model pembelajaran yang disampaikan hendaknya lebih mengutamakan hal yang bisa dilakukan guna memberikan beberapa pilihan dalam pembelajaran biologi yang akan diajarkan dan selaras dengan tingkat perkembangan siswa. Hal ini berarti 
bagus atau tidaknya suatu model tergantung pada tujuan pembelajarannya, kepasan dengan materi yang disampaikan, perkembangan peserta didik, serta kepandaian guru mengelola, mempersiapkan dan juga memanfaatkan segala sumber belajar yang tersedia.Siswa harus didorong untuk dapat berpikir, menganalisis, berpendapat, mempraktikan, dan menerapkan pembelajaran yang akan mereka dapatkan dan siswa bukan hanya sekedar menjadi pendengar pasif, tetapi guru benar-benar mengarahkan, atau membentuk suasana pembelajaran yang sebaik mungkin sehingga siswa bisa menikmati suguhan pembelajaran.

Berdasarkan permasalahan di atas, hendaknya guru biologi memilih dan menerapkan model pembelajaran yang mampu merangsang daya tarik peserta didik sehingga lebih aktif dalam pembelajaran biologi. Salah satu model pembelajaran yang dapat diterapkan yaitu model pembelajaran Inquiry.Model Inquiry merupakan salah satu langkah yang bisa ditempuh untuk memperbaiki hasil belajar siswa khususnya pada mata pelajaran biologi. Menurut Kurniasih \& Sani (2015) ilmu dan keahlian yang diperoleh siswa bukan hasil mengingat tetapi hasil menemukan sendiri melalui pengamatan, percobaan (eksperiment) dan eksplorasi. model pembelajaran Inquiry merupakan pembelajaran dengan seni merekayasa situasi-situasi kondisi yang bisa diatur sebagaimana mungkin dimana peserta didik bisa menjadi seorang penemu. Jenis inquiry yang akan dilakukan adalah inquiry terbimbing dengan bantuan LKS, dikarenakan ini adalah pertama kali dilakukan di kelas tersebut.

\section{METODE PENELITIAN}

Jenis penelitian ini yaitu menggunakan metode eksperimen murni. Menurut Arikunto (2010), penelitian eksperimen untuk mengetahui dampak sesuatu kejadian atau variable yang dilakukan oleh si peneliti. Sedangkan menurut Sugiyono (2012), penelitian eksperimen untuk mengetahui pengaruh perlakuan tertentu yang diterapkan terhadap hasil yang diinginkan dalam kondisi yang terkendalikan.

Desain penelitian yang digunakan adalah pre-test-pos-test control group design (Arikunto, 2010) yang terdapat dua kelompok sampel yaitu kelompok eksperimen dan kelompok kontrol. Adapun desain penelitian yang digunakan berbentuk pretest-posttest control group design. Menurut Arikunto (2010) desainnya dapat dilihat pada tabel.1.

Tabel 1 Desain Penelitian

\begin{tabular}{cccc}
\hline Group & Pre-test & Treatment & Post-test \\
\hline $\mathrm{E}$ & $\mathrm{O} 1$ & $\mathrm{X}$ & $\mathrm{O} 2$ \\
\hline $\mathrm{K}$ & $\mathrm{O} 3$ & & $\mathrm{O} 4$ \\
\hline
\end{tabular}

Keterangan

E : Kelas eksperimen 


$\begin{array}{ll}\mathrm{K} & \text { : Kelas control } \\ \text { 01 dan 02 } & \text { : Pre-test dan post-test pada kelas eksperimen } \\ \text { 03 dan 04 } & \text { : Pre-test dan post-test pada kelas control } \\ \mathrm{X} & \text { : Perlakuan dengan model Inquiry } \\ - & \text { : Model pembelajaran konvensional }\end{array}$

Populasi yang digunakan adalah seluruh siswa kelas X SMA Negeri 6 Lubuklinggau tahun pelajaran 2015/2016 yang terdiri atas enam kelas, sampel adalah kelas X.1 sebagai eksperimen dan kelas X.2 sebagai control yang diambil secara acak (samplerandom). Teknik pengumpulan data dalam penelitian ini adalah teknik tes. Arikunto (2010), menyatakan bahwa tes adalah beberapa pertanyaan atau latihan yang dipakai untuk mengukur keahlian, kecerdasan pengetahuan, dan bakat yang dimiliki oleh individu atau kelompok.

Tes yang digunakan berupa butir soal essay sebanyak enam buah yang sesuai dengan standar kompetensi,kompetensi dasar dan indicator pembelajaran.Tes diberikan sebanyak dua kali pada setiap kelas, yaitu kelas eksperimen dan kelas control yaitu tes kemampuan awal atau (pre-test) dan tes kemampuan akhir (post-test). Data yang didapat dianalisis dengan uji-t pada taraf signifikan $\alpha=0,05$.

\section{HASIL PENELITIAN}

Penelitian dilaksanakan pada tanggal 25 April 2016 sampai dengan tanggal 25 Mei 2016 dengan tujuan untuk mengetahui efektivitas model pembelajaran inquiry terhadap hasil pembelajaran biologi pada kelas X SMA Negeri 6 Lubuklinggau. Pada penelitian ini, sebelum proses belajar-mengajar terlebih dahulu peneliti melakukan pre-test. Pemberian pre-test dilakukan pada pertemuan pertama yaitu tanggal 02 Mei 2016 yang diikuti 37 siswa pada kelas eksperimen dan tanggal 07 mei 2016 untuk kelas control yang ikuti 36 siswa. Tujuan dilakukannya pre-test ini untuk mendapatkan hasil kemampuan awal siswa sebelum mengikuti pembelajaran biologi dengan menerapkan model pembelajaran inquiry yang diterapkan di kelas eksperimen.

\section{Deskripsi dan Analisis Data Tes Awal (Pre-test) Kelas Eksperimen dan Kelas Kontrol}

Hasil perhitungan nilai rata-rata dan simpangan baku nilai pre-test kelas eksperimen (32,84 dan 7,95) dan kelas kontrol (29,33 dan 8,37).Uji normalitas dalam penelitian ini bertujuan untuk mengetahui apakah data hasil Pre-test siswa dikedua kelas berdistribusi normal. Berdasarkan table 2 di bawah ini dapat disimpulkan kedua data berdistribusi normal yaitu kelas eksperimen didapat nilai $\mathrm{t}$ hitung =1,6819 dan pada kelas kontrol didapat nilai $\mathrm{t}$ hitung $=4,8950$. Rekapitulasi hasil uji normalitas dapat dilihat pada table 2 berikut ini. 
Tabel 2. Hasil Uji Normalitas Nilai Pre-test

\begin{tabular}{lccc}
\hline \multicolumn{1}{c}{ Kelas } & Dk & \\
\hline Eksperimen & 1,6819 & 6 & 12,592 \\
\hline Kontrol & 4,8950 & 6 & 12,592 \\
\hline
\end{tabular}

- Setelah diketahui bahwa data berdistribusi normal maka dilanjutkan dengan pengujian homogenitas sampel yang bertujuan untuk mengetahui keadaan varians kedua kelompok seragam atau tidak. Varians sampel yang diambil dari kelas eksperimen dan kelas kontrol. Berikut ini rekap data hasil uji homogenitas varians pre-test pada taraf kepercayaan $\alpha=0,05$ dapat dilihat pada table 3 .

Tabel 3. Hasil Uji Homogenitas Nilai Pre-test

\begin{tabular}{ccccc}
\hline Kelas & t-hitung & Dk & t-tabel & Kesimpulan \\
\hline Pre-Test & 1,11 & $36: 35$ & 1,72 & Homogen \\
\hline
\end{tabular}

Berdasarkan table 3 di atas menunjukan kedua data pre-test adalah homogen. Berdasarkan hasil uji normalitas dan uji homogenitas yang telah peneliti lakukan, maka dapat disimpulkan bahwa kedua kelas eksperimen dan kontrol pada data pre- test adalah normal dan homogen. Untuk menjawab hipotesis penelitian yang telah dibuat maka peneliti melakukan uji hipotesis dengan menggunakan uji dua kesamaan rata-rata dengan menggunakan uji t. Hasil uji hipotesis yang diperoleh peneliti untuk nilai pre-test dapat dilihat pada table 4 .

Tabel 4. Hasil Uji Hipotesis Nilai Pre-test

\begin{tabular}{|c|c|c|c|c|}
\hline Test & t hitung & & & Kesimpulan \\
\hline Pre-Test & 1,84 & 2,00 & thitung & $<$ ttabel, Ho diterima \\
\hline
\end{tabular}

Berdasarkan hasil perhitungan uji hipotesis pada table 4 hasil penelitian menunjukkan bahwa nilai yang diperoleh untuk thitung $=1,84$ dan ttabel $=2,00$. Sesuai dengan ketentuan perhitungan statistik mengenai pengujian hipotesis dengan taraf kepercayaan sebesar 0,05jika thitung <ttabel maka peneliti dapat menyimpulkan,nilai rata-rata kelas eksperimen dan kelas Kontrol adalah sama, maka Ho diterima dan Ha ditolak.

\section{Deskripsi dan Analisis Data Tes Akhir (Post-Test)Kelas Eksperimen dan Kelas Kontrol}

Pada penelitian ini, setelah melakukan pre-test, peneliti meneruskan dengan melakukan proses belajar mengajar,dimana kedua kelas eksperimen dan control dalam penelitian ini mendapatkan perlakuan yang berbeda sesuai dengan model pembelajaran. Pada kelas X.1 diterapkan model pembelajaran Inquiry sedangkan pada kelas X.2 diterapkan model pembelajaran konvensional,namun 
dengan memberikan bahan materi yang sama yaitu sama-sama diberikan materi Ekosistem. Hasil perhitungan nilai rata-rata dan simpangan baku post-test kelas eksperimen(78,18 dan 10,39) dan kelas $\operatorname{kontrol}(6,89$ dan 9,49). Uji normalitas bertujuan untuk mengetahui apakah data hasil post-test siswa dikedua kelas berdistribusi normal. Rekapitulasi hasil uji normalitas dapat dilihat pada table 5 .

Tabel 5. Hasil Uji Normalitas Nilai Post-test

\begin{tabular}{lllll}
\hline \multicolumn{1}{c}{ Kelas } & t-hitung & Dk & t-tabel & Kesimpulan \\
\hline Eksperimen & 10,2545 & 6 & 12,5920 & Normal \\
\hline Kontrol & 10,8092 & 6 & 12,5920 & Normal \\
\hline
\end{tabular}

Berdasarkan table 5 dapat disimpulkan kedua data berdistribusi normal yaitu kelas eksperimen didapat nilai thitung $=10,2545$ dan pada kelas kontrol didapat nilai $\mathrm{t}$ hitung $=10,8092$. Setelah diketahui bahwa data berdistribusi normal maka dilanjutkan dengan pengujian homogenitas sampel yang bertujuan untuk mengetahui keadaan varians kedua kelompok seragam atau tidak. Varians sampel yang diambil dari kelas eksperimen dan kontrol. Berikut ini rekap data hasil uji homogenitas varians post-test pada taraf kepercayaan $\alpha=0,05$ dapat dilihat pada table 6 .

Tabel 6 Hasil Uji Homogenitas Nilai Post-test

\begin{tabular}{|c|c|c|c|c|}
\hline Kelas & & $\mathrm{Dk}$ & & Kesimpulan \\
\hline Post-Test & 1,12 & $36: 35$ & 1,72 & Homogen \\
\hline
\end{tabular}

Berdasarkan table 6 di atas menunjukan kedua data adalah homogen. Berdasarkan hasil uji normalitas dan uji homogenitas yang telah di lakukan,dapat disimpulkan bahwa kedua kelas eksperimen dan kontrol pada data post-test adalah normal dan homogen. Karena data berdistribusi normal dan homogen, maka dilakukan uji kesamaan dua rata-rata dengan menggunakan uji t. Hasil uji hipotesis yang diperoleh peneliti untuk nilai post-test dapat dilihat pada table 7 .

Tabel 7. Hasil Uji Hipotesis Nilai Post-test

\begin{tabular}{|c|c|c|c|}
\hline Test & t hitung & t-tabel & Kesimpulan \\
\hline Post-Test & 4,06 & 1,67 & thitung $>$ ttabel, Ho ditolak \\
\hline
\end{tabular}

Berdasarkan hasil perhitungan uji hipotesis pada tabel7 hasil penelitian menunjukkan bahwa nilai yang diperoleh untuk thitung $=4,06$ dan ttabel $=1,67$. Sesuai dengan ketentuan perhitungan statistik mengenai pengujian hipotesis dengan taraf kepercayaan $=0,05$ jika thitung $>$ ttabel maka peneliti dapat menyimpulkan bahwa nilai rata-rata kelas eksperimen dan kelas kontrol adalah tidak sama, maka Ha diterima dan Ho ditolak. 


\section{Analisis Indek Gain}

Peningkatan Hasil belajar siswa berdasarkan berdasarkan data prêt-test dan post-test siswa dengan penerapan model inquiry pada kelas $X$ SMAN 6 Lubuklinggau. Hasilnya dapat dilihat pada table berikut.

Tabel 8. Hasil Perhitungan Gain

\begin{tabular}{|c|c|c|}
\hline & Gain & Kategori \\
\hline Kelompok Eksperimen & 0,6751 & Sedang \\
\hline Kelompok kontrol & 0,5739 & Sedang \\
\hline
\end{tabular}

\section{PEMBAHASAN}

Permasalahan yang akan dibahas adalah efektivitas model pembelajaran inquiry terhadap hasil belajar pada siswa kelas X SMA Negeri 6Lubuklinggau. Berdasarkan analisis data post-test terdapat perbedaan hasil belajar antara kelas eksperimen dan kelas kontrol. Kedua kelompok diberi perlakuan yang berbeda,yaitu kelompok eksperimen diberi tindakan menerapkan model pembelajaran inquiry sedangkan kelompok control diberi tindakan dengan menerapkan model pembelajaran konvensional.

Model pembelajaran konvensional yaitu model pembelajaran yang biasa digunakan oleh pendidik dalam perlakuan pembelajaran dikelas yaitu dengan menggunakan metode seperti ceramah, Tanya jawab, pelaksanaan pembelajaran diberikan sebanyak dua kali pertemuan untuk melihat perbedaan hasil belajar yang dialami oleh siswa. Tujuan pembelajaran dengan menerapkan model pembelajaran inquiry adalah untuk memotivasi siswa agar siswa mandiri dalam belajar dan keterampilan dalam menyampaikan pendapatnya dan juga mengembangkan kreatifitasnya dalam belajar.

Pada pertemuan pertama dikelas eksperimen tanggal 2 Mei 2016 terdapat sedikit hambatan yaitu kegaduhan siswa ketika pembagian kelompok berlangsung karena jumlah kelompok banyak,untuk menjelaskan materi tentang Ekosistem. Dalam hal ini guru hanya sebagai fasilitator yang membantu dalam pembelajaran, siswa bekerja sendiri dengan kelompoknya dan mencari jawaban yang ada pada lembar kerja siswa (LKS). Selanjutnya diakhir pembelajaran siswa dibimbing untuk menyampaikan hasil diskusi kelompoknya didepan kelas dan kelompok lain menanggapi. Hal ini dapat memudahkan siswa untuk memahami dan mengingat kembali apa yang telah dipelajari karena pengetahuan yang dibangun sendiri oleh siswa baik secara individu maupun kelompok.

Pada pertemuan kedua siswa sudah mulai memahami langkah-langkah pembelajaran inquiry yang baru mereka terapkan. Dari 37 siswa 29 siswa yang telah dibentuk dalam kelompok mulai menikmati pelajaran yang mengakibatkan mereka aktif dalam belajar, siswa yang lain masih membutuhkan bimbingan guru dalam proses pembelajaran, salah satu kelemahan dalam model 
pembelajaran inquiry ini adalah masih ada beberapa siswa yang takut mengungkapkan atau memaparkan hasil diskusi mereka.

Pembelajaran yang dilaksanakan dikelas control pada pertemuan pertama pada tanggal 07 Mei 2016, kedua pada tanggal 21 Mei 2016. Pada pembelajaran yang dilaksanakan dikelas control juga mengalami beberapa kendala dalam mengajar seperti siswa yang sibuk becerita dengan teman sebangku, ada yang sibuk dengan kegiatannya dan ada juga yang hanya diam saja. Sampai pertemuan terakhir dengan menggunakan pembelajaran konvensional. Dimana proses pembelajaran ini lebih banyak dikendalikan oleh peneliti, siswa hanya duduk memperhatikan peneliti menerangkan atau menjelaskan materi.

Hal semacam ini justru mengakibatkan peneliti tidak mengerti pemahaman siswa, karena siswa yang sudah tahu atau yang belum mengerti hanya diam saja. Siswa belum mengerti tentang materi yang diajarkan tidak berani untuk bertanya. Ketika diminta untuk mengerjakan soal,siswa cenderung asyik bercerita dengan temannya, malas dan diam saja. Pada pembelajaran konvensional ini ternyata memiliki kelemahan dimana proses belajar hanya didominasi oleh guru. Hal ini cenderung peserta didik pasif dan kurang aktif dalam pembelajaran,siswa hanya mencatat, mendengar dan sedikit bertanya. Sehingga pada saat evaluasi banyak yang mengalami kesulitan dalam menjawab pertanyaan karena sebenarnya mereka belum paham dan mengerti dengan materi yang telah dipelajari.

Berdasarkan analisis pre-test dan data pos-test hasil belajar kedua kelompok dilakukan uji normalitas, uji homogenitas,dan uji kesamaan dua ratarata menunjukkan bahwa kedua kelompok berdistribusi normal, dan homogen berarti rata-rata nilai kelas eksperimen lebih tinggi dari pada rata-rata nilai pada kelas kontrol. Sehingga dapat disimpulkan bahwa ada pengaruh pada model pembelajaran Inquiry terhadap hasil belajar biologi siswa kelas X SMA Negeri 6 Lubuklinggau tahun pelajaran 2015/2016.

Penelitian yang telah dilakukan sebelumnya oleh Sundari (2014) dengan judul Pengaruh Metode Inquiry terhadap Hasil Belajar Fisika Siswa di SMANegeri 2 Kota Lubuklinggau. Sedangkan penelitian yang dilakukan oleh Rosminarti (2014) yang berjudul Pengaruh Model Pembelajaran Inquiry Terbimbing terhadap Hasil Belajaran dan Keterampilan Proses Sains Siswa Kelas X SMA Negeri Tugumulyo Tahun Pembelajaran 2013/2014. Berdasarkan hasil analisis data telah terbukti bahwa terdapat perbedaan antara keterampilan proses kelas siswa yang menggunakan model pembelajaran inquiry dengan kelas siswa yang menggunakan model pembelajaran knvensional.

Berdasarkan penelitian Nugroho (2010) dengan judul Pembelajaran Biologi dengan Metode Inkuiry Terbimbing Menggunakan Laboratorium Riil Ditinjau dari Kemampuan Memori Dan Gaya Belajar Siswa SMA Negeri 1 Surakarta. Dengan hasil penelitian yang diperoleh bahwa nilai rata-rata Pembelajaran Biologi dengan Metode Inkuiri Terbimbing meningkat. Berdasarkan hasil dari kelima penelitian terdahulu dan hasil penelitian yang dilakukan dapat 
disimpulkan bahwa ada pengaruh Inquiry terhadap hasil belajar siswa dikelas $\mathrm{X}$ SMA Negeri 6 Lubuklinggau

\section{SIMPULAN}

Hasil penelitian yang dilakukan peneliti dapat disimpulkan bahwa model pembelajaran inquiry efektiv untuk pembelajaran biologi pada siswa kelas $\mathrm{X}$ SMA Negeri 6 Lubuk linggau. Dapat dilihat dari hasil uji kesamaan dua rata-rata hipotesis pre-test yaitu t-hitung 1,84 nilai t-tabel 2,00 maka thitung < ttabel. Sedangkan nilai uji kesamaan rata-rata Post-Test yaitu dengan t-hitung 4.06 nilai t-tabel 1.67 maka disimpulkan t-hitung > t-tabel. Gain pada kelompok eksperimen $=0,6751$ dengan kategori sedang dan gain kelompok control $=0,5739$ dengan kategori sedang.

\section{DAFTAR PUSTAKA}

Ahmadi, A \& N, Uhbiyati. (2013). Ilmu Pendidikan. Jakarta. Rineka Cipta.

Arikunto, S. (2010). Prosedur Penelitian Suatu Pendekatan Praktek. Jakarta: Rineka Cipta.

Kurniasih, I \& B, Sani. (2015). Model Pembelajaran. Jakarta. Kata Pena.

Nugroho, S. (2010). Pembelajaran Biologi Dengan Metode Inkuiri Terbimbing Menggunakan Laboratorium Riil Ditinjau dari Kemampuan Memori Dan Gaya Belajar Siswa SMA Negeri 1 Surakarta. Ejurnal Bunggata. 50(3), 235-244.

[Online]. http://Ejurnal.Bunghatta.ac. Id/index.[15 Febuari2016].

Rosminiarti, L. (2014). Pengaruh Model Pembelajaran Inquiry terhadap Hasil Belajar dan Keterampilan Proses Sains Siswa Kelas X SMA Negeri Tugumulyo. Skripsi. Tidak Diterbitkan Lubuklinggau STKIP-PGRI Lubuklinggau.

Supriyadi. (2014). Strategi Belajar Mengajar. Yogyakarta : Cakrawala Ilmu.

Sugiyono. (2012). Metode Penelitian Kombinasi (mixed methods). Bandung:Alfabeta.

Sundari, A. (2014). Pengaruh Model Pembelajaran Inquiry terhadap Hasil Belajar Fisika Kelas X SMA Negeri 6 Lubuklinggau. Skripsi. Tidak Diterbitkan Lubuklinggau STKIP-PGRI Lubuklinggau. 